\title{
Local Wisdom Based on Riau-Malay Language in Kuantan Singingi Regency
}

\author{
Hasnah Faizah AR, Auzar, Fakhri Ras \\ Universitas Riau \\ hasnahfaizah68@gmail.com
}

\begin{abstract}
This article discussed about the local wisdom that was found in the Kuantan Singingi community based of Riau-Malay especially Kuantan Singingi dialect. The purpose of this research is to analyze the form and field of meaning of local wisdom based on Malay language in Kuantan Singingi Regency. The method used with qualitative-descriptive approach. The data collecting techniques used technique of referring, technique of note, and technique of interview (cakap semuka) by used instrument of Swades vocabulary and addition of certain vocabulary variation. The results obtained were the form of lexical phonetic innovation in this study was found as many as 11 glos with 33 variants that still retain local wisdom in Kuantan Singingi community that is khitanan, berkebun, hajatan, kerja bakti, tukang menggali kuburan, tukang memandikan mayat, tukang pantun, tunangan, yasinan, menuju hari, and menuju bulan, while the morphological innovations found in this study were 22 gloss with 75 variants, that is 1) morpheme ber-become bo-, ba-, mo-, ma-, and morpheme release ber-; 2) morpheme me- becoming morpheme bo-, ma-, mo-, and ba-; 3) morpheme pebecoming morpheme po- and pa-; 4) morpheme be- becoming morpheme bo- and ba-; and morpheme men-becoming morpheme moand ma-. Fields of meaning of Riau Malay language as the local wisdom of Kuantan Singingi's innovative community are found 12 (twelve) mean fields, namely: kinship 20 glos, village life 18 glos, house and surrounding 22 glos, household appliances and sleep equipment gloss, plants and fruits 14 glos, tools and fishing rod 15 glos, food and beverage 24 glos, nature and flavor 19 glos, color 18 glos, activity 50 gloss, musical instrument 6 glos, clothing and 13 gloss jewelry.
\end{abstract}

Keywords-Lokal Wisdom; Malay Riau; Lexical Innovation; Kuantan Singingi Society

\section{INTRODUCTION}

Language as a communication system has aspects of the form, ie aspects related to the writing, structure, or sound of the language itself. In addition, the language also has aspects of meaning, namely aspects related to grammatical, functional and lexical. The difference between the lexical aspect and aspect can be known from the disclosure used to produce variations of language, it can be due to social factors, changes in time, the conditions and the formal situation, and the geographical position of the speakers of the language itself. The language variations that arise from individuals, are called idiolects. Chaer (2011) also states that this variation of idiolek is pleased with the color of sound, word choice, style of language, sentence arrangement and so on. However, these variations differ only in small scales, whereas the rough lines of language remain no different in individuals with different regions but with geographical similarities. For example, cultural differences and disappearances can be identified in the language that occurs in the Malay dialect of Kuantan Singingi district. The use of language in the Kuantan Singingi community describes local wisdom or local cultural wisdom as a communication tool, but there are differences in the language used. Based on these dynamics, researchers conducted a study "Local Wisdom-Based Malay Riau in Kuantan Singingi Regency". The purpose of this research is to analyze the forms of innovation of local wisdom based on Malay in Kuantan Singingi regency and to analyze the forms of local wisdom-based meaning field of Malay language in Kuantan Singingi district. This study focuses on the study of cultural and linguistic fields, especially the study of Malay-based local wisdom in Kuantan Singingi district. So, this research seeks to identify local language-based wisdom. Theoretically, this research is expected to provide the development of science to culture and linguistics in general and dialect geography in particular, and can be used for reference for further research. Practically, this research is also expected to be able to document one element of culture in Riau province. This geolinguistic study is expected to represent cultures represented through language can be recorded and documented, given the dynamic nature of the language that can evolve over time.

In accordance with the purpose of research, then used several theories. Opinions, Ayat Rohaedi (1983), Keraf (1993), Wahya (2005), and Chaer (2011) are used as theories relating to dialect and culture studied. The verses of Rohaedi (1983) distinguish dialects into five kinds: (1) phonetic differences, (2) semantic differences, (3) onomasiological differences, (4) semasiological differences, and (5) morphological differences. According to Wahya (2005) dialect is a form of language variation, both in a social environment and a particular geographical environment. Opinion Verse Rohaedi (1983) about the field of meaning is that the field of meaning is contained in every word spoken. As the meaning field contained in the word 'omak' the meaning of the child's call to the female parent and on the word 'pembengak' which mean liar or dishonest. 
Edwar T. Hall (1973) in Mulyana (2011) is an anthropologist, who states that culture is communication and communication is culture. Simply put, "it is impossible to think of communication without thinking about its cultural meaning and context" (see Keraf, 1993). Culture has the ability to determine the way communication is the topic of speech, speaker or listener, how and when, body language, the concept of space and warktu, and meaning, all of this is strongly influenced by culture. Culture can be defined as the result of thought or thought, so it can be seen that language and thought have a reciprocal correlation that the mind is meant to be a manifestation of culture. Experts agree that language is a "tool" in the communication process, which can be used and utilized.

Language can also influence groups, this is explained by Dede Oetomo (Syam, 2012). This theory emerged from the observation of the everyday speech of the Chinese ethnic community of Pasuruan. According to him, Chinese society can be grouped into Chinese Peranakan and Chinese Totok. Thus, he concludes that language can reflect the identity of the group. There are certain forms used by speakers of the two different dialects in marking the indirect inference to their communication which can only be understood by speakers of the dialect (Rilley, 2009) According to Chaer and Leoni Agustina (2010) language is a tool of verbal communication and also as an arbitrary sound symbol for the community to be able to interact and communicate personal identity. In addition, language is used as a message in the communication process, as a result of cultural production that contains the values and norms of society.

Some theories related to language and culture are below:

a. Sapir and Whorf's Linguistic Relativity Theory, Sapir (1884-1939). Sapir human life gained because of the sense of language compassion as a means of introduction in social interaction. In addition, Sapir argues that the formation of a culture of most of the language's behavior in the culture (Sapir, 2017). Language can also specify specific interpretation options so that it can serve as a guide to social reality. The results of his research on language then led to the theory of linguistic relativity or also called Sapir-Whorf hypothesis, whose contents are not guided by the same physical evidence to get the same life images, unless their linguistic backgrounds are the same or can be equated in one way. Different languages study this nature in different ways, thus creating a relativity of different conceptual systems also depending on the various languages. Grammar is not only a means of conveying ideas but is an idea-shaper. (Storey, 2003).

b. The theory of Wilhelm Von Humboldt, the German scholar of the nineteenth century. The theory is that human beings as social beings communicate, behave, and behave as perceptions, and the process fused between language and perception. Von Humboldt concludes that there is human dependence on language. Culture and language are directly proportional, the more cultures are known, the more understood the language and the better the self-identity used in that culture. Language has an undeveloped mind set formed by Ideenform / Innereform and sounds pronounced so that language becomes synthetic from un-formed thinking and sounds pronounced (Keraf, 1993).

According to the theory of Wilhem Von Humboldt and the theory of Linguistic Relativity can be postulated that there are two relations between cultures and languages, namely: Subordinate which means the study of language based on the entities that exist in the culture itself. Thus, culture and language can not be separated and related to the meaning of culture and its context. Theoretically, the true meaning of value is integrated as human experience and consciousness for fellow human beings with confidence can be socially responsible (horizontal) and vertical to the Creator. Values have meaning as meaning something, the meaning of something, and the level of intelligence or ability of something, besides, value also refers to the weight of something, value is the price of something, and value is the essence of something (Ratna, 2013).

Robert M.Z Lawang (2014) concludes that values as a description of what is appropriate, what is valuable, what is desired, and what may affect the social behavior of those who have that value. Similarly, the Islamic religion contains the normative teachings about the good that must be done by humans, and bad things that must be avoided by humans. Human life has an integral value system consisting of social-cultural values, national national values, national values of nationality, constitutional national values, and natural human values. Hamidy, (2010) that value has a meaning as a price, but does not have a standard measure in determining the amount of substance, quality, and rules. Value is divided into four main points, namely ethical / ethical, aesthetic / beauty, truth, and religious.

The Riau provincees language is categorized into 7 languages in Riau archipelago, 5 languages in Bengkalis district, 6 languages in Indragiri Hilir district, 4 languages in Indragiri Hulu district, and 6 languages in Kuantan Singingi district. The dialect of the Riau Malay language consists of Indragiri Hulu dialect, Kampar,Indragiri Hilir, Bengkalis, Kuantan Singingi. Kuantan Singingi consists of Kampar Malay dialect, covering 13 koto Kampar, Kampar Kiri, Kampar Hilir Kampar Hulu, Kuantan Singingi Hulu, Stone Painted, and some nearby areas within Kampar regency; Malay dialect Indragiri Hulu (Indragiri Hulu district, except Talang Mamak community); Malay dialect of Indragiri Hilir (Melayu Mandah); Malay dialect Bengkalis covers Bengkalis Regency, and Dumai Municipality; the dialect of Kuantan Singingi dialect of Kuantan Singingi and Pekanbaru Town; the Kuantan Singingi dialect of the Malay language includes the koto 
Taluk Kuantan, Benai, Sentajo, Pangean, Baserah, Muara Lembu, Kari, Lubuk Jambi, Singingi, Simandolak, Cerenti, regions Kuantan Singingi; Malay Talang Mamak language is in six kebatinan; Akit languages include Rupat, Long Forest, Titi Root, and Rupat Island areas; Petalangan language covers Bunut area; Bonai language in Kuntodarussalam;; district Kuantan Singingi district; language of forest people in the Rangsang area Sakai language includes Minas and Duri areas;

Kuantan Singingi regency consists of twelve sub-districts, namely: Benai, Cerenti, Toar, Hulu Kuantan, Inuman, Kuantan Hilir, Kuantan Mudik, Kuantan Tengah, Pangean and Singingi Hilir. Kuantan people tend to be fanatical in using the Kuantan dialect in their daily lives, Kuantan people who are outside Kuantan regency areas tend to prefer to use the language when they meet other people who come from Kuantan regency. Boundary of Kuantan Singingi Regency, North with Kampar and Pelalawan districts, South with Jambi, West with West Sumatera, and East with Indragiri Hulu Regency.

\section{METHODS}

Descriptive research carried out by interpreting the phenomenon of data, variables, and that exist in place of research. A qualitative approach is undertaken to understand the social dynamics in the linguistic aspect being studied (Mahsun 2005: 235). Source of data in this research come from informant at every point of observation. The informants of this study were selected using the criteria proposed by Nothofer (2007) and Fernandez (2007). In geographic dialect research, the research informants were chosen with criteria: 1) male or female sex, 2) aged 30 s.d. 65 years; 3) born and raised in the local village; 4) can speak Kuantan Singingi; 5) can speak Indonesian; and 6) healthy in spirit and body in the sense of perfect speech;

This research was conducted in Kuantan Singingi regency, Riau province consist of 6 locations of observation point, Singingi Hilir sub-district, Kuantan Tengah sub-district, Singingi sub-district, Gunung Toar sub-district, Kuntan Mudik sub-district and Hulu Kuantan sub-district. The questionnaire to be addressed to the informant is based on 200 Swadesh's basic vocabulary which is then developed into 370 basic vocabulary questions, and the later cultural vocabulary of which is selected and combined according to the meaning field. The questionnaire on this study is categorized into eighteen mean fields, including: kinship 20 glos, village life 18 glos, house and surrounding 22 glos, household appliances and bedding 20 glos, plants and fruits 14 glos, animals 23 glos, gloss, food and beverage 24 glos, disease 18 gloss, nature and taste 19 glos, state and color 18 gloss, nature about 26 glos, body parts 28 glos, activity 50 gloss, musical instrument 6 glos, clothes and 13 gloss jewelry, 20 gloss numbers, 20 gloss point and pronouns.

Technique of collecting data using skill method or interview and method refer. This method is used to gather information about lexical or vocabulary based on questionnaire asked. These techniques through the conversation is done between the informant and the researcher. Interview method or skill is a technique of data collection taken from the conversation between the informant and the researcher. The basic technique in this method is implemented by stimulus or fishing techniques that are arranged on a questionnaire. The method of referring is done by listening to the speaker's entire language conversation. This method is used to listen to the use of language by informants. In this case, researchers play a role in listening to the language of the informant and record and record things that are important. These records and records are required to complete the data. In addition, the method is also used skillfully (see Sudaryanto, 2011).

Technique of data analysis is technique of "hubung banding menyamakan" (Mahsun, 2005). The implementation was done by determining the internal innovation of Riau Malay language in the research location using one variant, named variant of meaning and variant of form. Further, it compared with other variants at different observation points on the isolate region. If there were differences data found, then the differences were the innovation of the point of observation.

\section{Forms of Malay Language Variation in Kuantan Singingi Regency}

Based on local wisdom, the data that innovate the Riau Malay language in Kuantan Singingi district consist of phonetic innovation, morphological innovation, and full lexical innovation

1.1.1. Phonetic Innovations

From the 370 glos used, there are 11 glos with 37 variants that still retain local wisdom in the Kuantan Singingi community. Based on the phonetic or pronunciation there is a lexical Innovation that describes the custom or tradition that is on the word ,khitanan “e become /bosunEt/, and /basunat/; word ,berkebun "e become /bokobun/, /bakobun/, /batani/, and /bakobon/; word ,hajatan"e become /mendo'a/, /badua/, and /mondoa/; word ,kerja baktiee become /gotoroyoy/, /taroyon/,

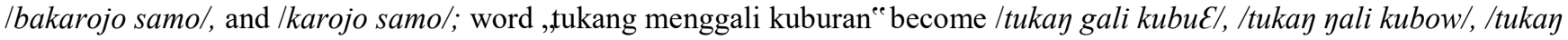
kali kubua/, /tukay kali kubuE/, tukay poyali tanah kubuar/, and /tukay maygali kubuar/; word ,tukang memandikan mayate

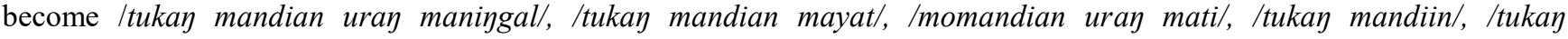
mamandian/, and /tukay mandiin moyi?/; word ,tukang pantun ${ }^{\text {ee }}$ become /botombo/, and /tukay saluay/; word ,tunangan ${ }^{\text {ee }}$ become /botando/,/batando/, /maantar tando/, /maantar ale?/; word ,yasinan“e become /yasinan/, /tahlial/, and /mayaji/; 
word „menuju harie become /monujua aRi/, and /manujua hari/; and word „menuju bulan become /monujua bulan/, and /manujua bulan/.

\subsubsection{Morphological Innovation}

he morphological innovations found in this study based on bound morphemes were found to be 22 gloss with 75 variants: 1) morpheme ber- become bo-, ba-, mo-, ma-, and release morpheme ber-; 2) morpheme me- become morpheme bo-, ma-, mo-, and ba-; 3) morpheme pe- become morpheme po- and pa-; 4) morpheme be- become morpheme bo- and ba-; and morpheme men- become morpheme mo- and ma-.

morpheme ber- become bo- and ba-, mo-, ma-, and release morpheme ber- for example ,berpantun become /bopantun/, /bapantun/; berkebun become /bokobun/, /bakobun/, /batani/; makan bersama become /makEn bosamo/, /makan

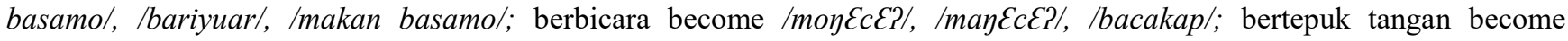
/botopua? tayan/, /batopua? tayan/, /topu? tayan/, /topua? ampai/;

Morpheme me- become morpheme bo-, ma-, mo-, and ba- for example menanam become $/ \mathrm{botanam} /$, $/ \mathrm{mananam} /$,

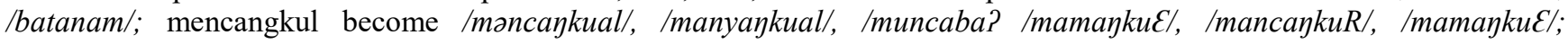
merantau become /moRantau/, /maRantau/, /maantau/; morpheme pe- become morpheme po- and pa- for example pemurah become /poagial, /pamuRa/, /jual, /paagiEl, /suko maagiah/;

Morpheme be- become morpheme bo- and ba- for example bekerja become /bokojo/, /bakojo/, /bakaRojo/; Morpheme men- become morpheme mo- and ma- for example menjalin (hair) become /moikE? obua?/, /mapiah obua?/, /malopia/, /malupiah/, /malopiah/.

\subsubsection{Full Lexical Innovation}

Based on the findings, obtained a full lexical innovation 19 data with 55 (fifty five) variants. These variants are set based on a different form with their original word form at every point of observation of Riau Malay in Kuantan Singingi district. This full lexical innovation are: mother become /əma?/, /omak?/; wife become /bini/; grandfather become /datua?/; oldest mom"s sister become /ma?tuo/, latua/, /ma?uwo/; middle mom"s sister become /ma?toyah/, /icia?/, /ma?ya/, /ma?yah/; mother"s little sister become /EtE?/, /ocia?/, /icia?/; calling word for boy become /buyuay/, /bujay/, /ujay/; calling word for daughter become /supia?/, /upia?/, /coni?/, /kaka?/, /conik/; oldest uncle become /ma? goday/, /mama? goday/, /anjay/, /mama?/; youngest uncle become /ma? EnE?/, /mama? kEtE?/, /mama?/; husband become /laki/;

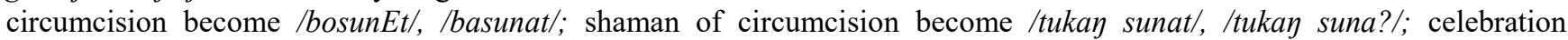
become /bado'a/, /badoa/, /badua/, /mondoa/; oil lamps become/damE/, /palito/; generous become /poagia/, /pamuRa/, /jua paagiE/, /suko maagiah/; tying hair become /moikE?/, /obua?/, /mapiah obua?/, /malopia/; bamboo trumpet become /sunai/, /sarunail, /sulliy/.

Although the observation area is close together, but the data is innovated or variant between one region and another. In addition, there are also areas that still use the same term in their language, such as the word husband become / men / there in Kuantan Tengah, Gunung Toar, Singingi, Hulu Kuantan, Kuantan Mudik, and Singingi Hilir.

\section{Forms of Meaning in Riau Malay Language as the Resignation of Local Wisdom in Kuantan Singingi Society}

Found in this study 11 mean fields, namely: 1) kinship 20 glos, 2) village community life 18 glos, 3) house and surrounding 22 glos, 4) household appliances and bedding 20 glos, 5) plants and fruits 14 glos, 6) tools and fishing rods 15 glos, 7) food and beverage 24 glos, 8) nature and flavor 19 glos, 9) 18 gloss colors, 10) 50 gloss activities, musical instruments 6 glos, 11) clothing and jewelry 13 glos. the data are as follows.

Based on kinship, for example the word ,adike become /adia?/ at 6 points of observation meaning 'younger siblings'; ,bapak" become / bapa?/ become two variants that mean 'male parents'; ,abang" become /abay/ meaning ,older brother" Based on the life of the village community such as ,tetangga" /tataygo/ become 3 variants /tatayga/, /tataygo/, /tataygo/, which meaning ,people whose house is close together". Based on the house and surrounding areas such as the ,halaman rumah" ,tonalamEn' become 5 variants /togalamEn/, /tonalaman/, /kaRayan umah/, /laman/, /laman rumah/, which meaning ,'land around the house ; , jendela" /komodEn/ become 4 variants /komodEn/, /pintu balobE/, / jandEla/, and /pintu/, which meaning, holes that can be closed and serve as places out of the air"e. Based on household appliances and bedding, for example ,kuncie become /kunci/ at 6 points of observation meaning 'tool for door holder, casket and so on'; „kamar" become /bilia?/ at 6 points of observation means 'space enclosed (closed) on the wall that becomes part of the house or building (usually blocked or limited by four walls); booth '; ,tempat nasie /tompE? boRE/, become 5 variants /tompE? boRE/, /kaRuay/, /sumpi? boRE/, /baladi/, and /guci hich means 'something used to put rice'. Based on plants and beverages, such as ,jambu bijie /jambu kotukal/ become 6 variants jambu kotukal/, /jambu pawE/, /jambu awE/, /jambu $m o \eta k a E /$, /jambu tampay/, and /jambu mogkE/, meaningful 'guava fruit in the flesh there are small seeds, the flesh is red or 
white.'; ,rumpute become /umpui?/ become 3 variants /umpui?/, /umpui/, and /rumpuiP/, meaning 'small trunked plant group'; kelapa become /koRambial/ become 3 variants /kaRambia/, /kambiu/, and /kəRanbiar/which means 'high-stemmed palm trees'.

Based on tools and fishing tools such ,pancinge / $\mathrm{kayial} /$, become 3 variants yaitu / kayial/, /kanyia/, and /panciay/,

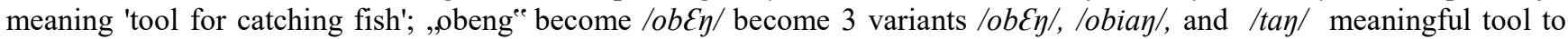
rotate the screws; ,kapak ${ }^{\mathrm{ee}}$ become $/ \mathrm{kapa}$ /, at 6 points of observation it means a tool for cutting down trees. Based on foods and beverages such as ,gulai asam pedas"e become /sompodEh/ become 5 variants /sompodEh/, /sampodE/, /asam podEh/, lasam podE/ and /sam podE/, which means 'curry sour taste and spicy '; getuk become /gotua?/ become 4 variants /gotua?/, /gatu?/, /galopuay/, and /obui ubi/ which means the food that comes from boiled yam then pounded and given sugar and coconut.

Based on the nature and feelings such as ,suka memberiee become /poagia/ become 6 variants /poagia/, /pamuRa/, /jua/, /paagiE/, /suko maagiah/, and /paagia/, means giving people to other people; ,ramah ${ }^{\text {ee }}$ become /poimbau/ become 4 variants /poimbau/, /panyapo/, /amah/, and /panyapo/ which means someone who likes to say hello when meeting with others; ,manis se become /mani/ become 2 variants /mani/ and /manih/, which means taste like sugar. Based on colour such as

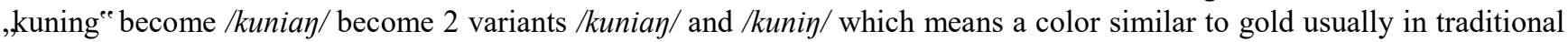
ceremonies.

Based on activities such as ,berpantun /bopantun/, become 2 variants /bopantun/ and /bapantun/ which means 'a language activity using pantun'; ,makan bersamae /makEn bosamo/become 3 variants /makEn bosamo/,/ makan basamo/, /bariyuar/ which means 'a meal activity in a rollicking manner, for example after a traditional ceremony'; ,mencangkule become /moncaykual/ become 5 variants /moncaykual/, /manyaykual/, /muncaba?/, /mamaykuE/, and /mancaykuR/ which means 'an activity undertaken to dig up the soil and clean up the fields or gardens by means of a hoe'. Based on musical instruments, such as ,kecapiee/kocapi/ become 3 variants /kocapi/, /kacapi/, and /gobo?/ meaningful' traditional string instrument stringed / three, five, six, tone and played with fingers'; , gendange /goyday/ didnt found any variant at 6 points of observation, it means 'traditional sound instruments of long logs in which there is a cavity and either a hole, both are given skin by being struck'. Based on clothing and jewelry, for example ,songket ${ }^{\text {ee }} /$ soykEt/ didnt found any variant at 6 points of observation, it means ,weaving embroidered gold or silver thread which is usually worn by women in traditional ceremoniesee.

\section{CONCLUSION}

1. The form of lexical phonetic innovation in this study was found as many as 11 glos with 33 variants that still retain local wisdom in Kuantan Singingi society that is khitanan, berkebun, hajatan, kerja bakti, tukang menggali kuburan, tukang memandikan mayat, tukang pantun, tunangan, yasinan, menuju hari, dan menuju bulan, as the morphological innovations found in this study are 22 gloss with 75 variants, among others: 1) morpheme is bo-, ba-, mo-, ma-, and release of morpheme ber; 2) morpheme transforms into morpheme bo-, ma-, mo-, and ba-; 3) morpheme pe- transforms become morpheme po- and pa-; 4) morpheme be- turned become morpheme bo- and ba-; and morpheme transforms into morpheme mo-m.

2. Field forms of meaning of Riau Malay language as the local wisdom resignation of Kuantan Singingi innovation found 12 (twelve) meaning field, which: kinship 20 glos, village life 18 glos, house and rooms 22 glos, household appliances and gloves, plants and fruits 14 glos, tools and fishing rods 15 glos, food and beverages 24 glos, nature 19 glos, colors 18 glos, activity 50 gloss, musical instrument 6 glos, clothes and jewelry 13 glos.

\section{References}

Ayatrohaedi. (1983). Dialektologi Sebuah Pengantar. Jakarta: Departemen Pendidikan and Kebudayaan Chaer, A. \& L. Agustina. (2010). Sosiolinguistik: Perkenalan Awal. Jakarta: Rineka Cipta.

Chaer, A. ( 2011). Lingustik Umum. Rineka Cipta: Jakarta.

Chambers, JK. (1980). Dialectology. Melbourne: Cambridge University.

Djajasudarma. (1996). Menyikapi Kosakata Bahasa Asing dalam Berbahasa Indonesia. Buku Bahasa and Sastra Indonesia. Bandung: HPBI and Yayasan Pustaka Wina.

Faizah, Hasnah \& J Yani (2016). Innovation in Language Melayu Lexical Riau Kuok Distric in the Study: Dialect Geography. International Journal of English and Education, 5 (3) Juli 2016 ISSN: 2278-4012

Fernandez, I Y. (koord). (2007). Sosiodialektologi Diakronis. Laporan Praktik Studi Lapangan. Yogyakarta: UGM.

Hamidy, UU. (2010). Kebudayaan Sebagai Amanah Tuhan. Pekanbaru:UIR Pres.

Keraf, Gorys. (1993). Linguistik Bandingan Historis. Jakarta: Gramedia Pustaka Utama.

Kridalaksana, H. (1993). Fungsi Bahasa dan Sikap Bahasa. Edisi II, Cet. I. Ende: Nusa Indah. 
Koentjaraningrat. (1995). Pembeda Dialek. Jakarta: PT. Cendikia Pelita

Lawang, R. M. Z. (2014). Tata Krama Lingkungan Masyarakat. Jakarta: Bumi Aksara

Mahsun. (2005). Dialektologi Diakronis. Yogyakarta: Gadjah Mada University Press

Mulyana, D. (2011). Komunikasi Lintas Budaya. PT Remaja Rosdakarya: Bandung.

Moleong, L. (2005). Metode Penelitian Kualitatif. Bandung: PT. Remaja Rosdakarya.

Ratna, NK. (2013). Estetika Sastra dan Budaya. Denpasar: Pustaka Pelajar.

Rilley, P. (2009). Language, Cultural dan Identity. London: Continum.

Sapir, E. (2017). Bahasa dalam Lintas Budaya. Yogyakarta: Bintang Persari.

Storey, P. (2003). Morfologi. Jakarta: PT Gramedia

Sudaryanto. (2011). Metode Linguistik Bagian Kedua Metode and Aneka Teknik Pengumpulan Data.Yogyakarta: Gadjah Mada University Press

Syam, A. (2012). Psikolinguistik. Jakarta: PT. Mutiara Cipta.

Wahya. (2005). Inovasi and Fungsi-Geografis Leksikal Bahasa Melayu and Bahasa di Perbatasan Bogor-Bekasi: Kajian Geolinguistik. (Disertasi) Bandung: PPS Universitas Padjadjaran. 